\title{
Analysis of the Readiness of LSP P1 "Tata Catering", Support for Teaching and Learning and Student Readiness for the Implementation of Competency Test in Unnes and Unesa Students
}

\author{
Saptariana $^{1}$, Sri Handajani ${ }^{2}$, Octavianti Paramita ${ }^{3}$, Maria Krisnawati ${ }^{4}$, Rina Rachmawati ${ }^{5}$ \\ \{saptariana@mail.unnes.ac.id ${ }^{1}$ \} \\ Family Welfare, Universitas Negeri Semarang, Indonesia ${ }^{1345}$ \\ Family Welfare, Universitas Sebelas Maret, Indonesia ${ }^{2}$
}

\begin{abstract}
Competency certification is an acknowledgment of workers who have knowledge, skills and work attitudes in accordance with the work competency standards required for each type of work. Currently there are several LPTKs that already have LSP P1. Surabaya State University (UNESA) already has "LSP Unesa", while Semarang State University (UNNES) is currently pioneering the establishment of "LSP Unnes". The objectives to be achieved from this research are: 1) knowing the Readiness of LSP P1 "Food Order" at UNNES and UNESA, 2) knowing the Teaching and Learning Process Support for the implementation of the Competency Test at UNNES and UNESA and 3) knowing the Readiness of Students for the Implementation of Competency Tests at UNNES and UNESA. This type of research is descriptive research, where the researcher tries to describe the events and incidents that are the center of attention without giving special treatment to these events. The subjects of this research are UNNES and Unesa Culinary Education students in semester 6 or 7 who will take the competency test, while the object of this research is the certification scheme and certification instruments, the quality of the process and the results of the competency test in LSP P-1, learning content (curriculum) which is in the PKK Unnes and Unesa department. The sampling technique in this study was total sampling. The data in this study were document data in the form of certification schemes and certification instruments, process mechanisms and quality of competency test results in LSP P-1, existing learning content (curriculum) in the PKK UNNES and Unesa department, while data on the readiness of Catering students for testing competency using a questionnaire. Data analysis in this research is descriptive statistics, in this research the descriptive statistics used are in the form of tables, percentages and brief descriptions of the readiness of LSP P-1, support for the teaching and learning process and student readiness for competency tests. The results of this study are 1) the readiness of LSP P1 "Catering" at UNNES for the competency test scheme has not been properly patterned because one scheme consists of three occupations, namely Second Chef Demi Chef, Assistant Head Chef. Meanwhile, the LSP P1 "Tata Catering" at UNESA has one scheme, there is one occupation, namely for the undergraduate scheme, the head of the kitchen and the diploma level scheme for the chef. 2) At Unnes and Unesa, academic support for competency tests has been well prepared because of the supporting courses that provide the knowledge required for competency tests in the culinary field 3) The results of the analysis of the readiness of students' knowledge for the competency test at Unnes: A: none, AB: none, B: 4 (8.33\%), BC: $10(20.83 \%), \mathrm{C}$ value: 13 people $(27.08 \%)$, CD value: 10 people $(20.83 \%)$, D value: 7 people $(14.58 \%)$, and E value: 4 people $(8.33 \%)$.
\end{abstract}

Keywords: Tata Catering; Student Readiness; Unnes; Unesa 


\section{Introduction}

The 2015 ASEAN Economic Community (AEC) is an integration of the ASEAN economy in the face of free trade between ASEAN countries. The existence of the AEC makes labor competition in the ASEAN region more open, where to be able to win this competition every worker in each country must have a qualified work competency provision, including Indonesian workers. This requires every Indonesian workforce to be able to compete with workers from other countries in the ASEAN region armed with a competency certificate if they do not want to be eliminated from the competition. Professional competency certification is one of the efforts to increase the competence of workers so that they are ready to face competition. In global competition, ownership certificate of professional competence is very important as authentic evidence on recognition of the competence of work covers aspects of knowledge (knowledge), skills (skills) and work attitude (attitude) in accordance with the standards of competence specified.

Competency certification is an acknowledgment of workers who have knowledge, skills and work attitudes in accordance with the work competency standards required for each type of work. Thus, competency certification will ensure that the workforce holding the certificate is guaranteed their competence in carrying out a type of work that is their duty and responsibility. Competency certification will influence and provide assurance, both to the holder or to other parties who employ the competency certificate holder. Educational Personnel Education Institutions (LPTK) are part of the creation of higher education graduates who have the responsibility to equip graduates with adequate competencies and are recognized in the world of work as qualified educational personnel. Likewise, LPTK graduates in the tourism sector must have a qualified pedagogical and vocational knowledge as well as a certificate of competence in the tourism sector.

The requirement to have competency certification in the tourism sector has been regulated in the Republic of Indonesia Government Regulation Number 52 of 2012 concerning Competency Certification and Business Certification in the Tourism Sector. What is meant by competency certification in the tourism sector is the process of granting competency certificates in the tourism sector carried out systematically and objectively through a competency test according to the Indonesian National Work Competency Standards (SKKNI) and / or international standards and / or special standards. Regarding competency certification in the tourism sector, the expert staff of the Ministry of Tourism (Kemenpar) I Gusti Putu Laksaguna said that: "The tourism industry is required to have competency certification to face tough competition, where competency certification will determine the quality and even the professionalism of services" (https: / /www.wartaekonomi.co.id).

So far, several LPTKs have pioneered the implementation of competency tests in the tourism sector for their graduates, although only through the LSP-P1 held by the LPTK. Given the requirements for a competency certificate for tourism workers who must be from LSP-P3, in the future a competency test model for LPTK students must be sought which allows them to have a competency certificate from LPS-P3 but does not have to do it off campus as a test site. competence. When this, passing the competency test LSP-P1 was sufficient for students who will complete his studies in LPTK. There are several LPTKs that already have LSP P1 on their campuses. Surabaya State University (UNESA) has for some time had an "LSP Unesa" which conducts competency tests for its students, including students from the Culinary Education study program who are included in the tourism competency test. Meanwhile, another LPTK campus, namely Semarang State University (UNNES) is currently pioneering the establishment of "LSP Unnes", so it is hoped that Unnes students can be provided with a 
certificate of competence for certain areas of expertise because competency tests can be carried out on their own campus by LSP P1 without having to cooperate with LSP from outside parties as has been implemented so far.

It can be said that the Unesa LSP has taken a step ahead of the Unnes LSP. LSP Unesa has / has prepared 37 competency test schemes and has conducted several competency tests of its schemes. Meanwhile, the Unnes LSP is still at the stage of compiling a competency scheme and preparing the facilities and infrastructure it has to be prepared as a Competency Test Center (TUK). The existence of Presidential Regulation Number 8 of 2012 concerning the Indonesian National Qualifications Framework (KKNI) further emphasizes that LPTKs must get closer to the needs of the world of work. Related to this, one of the efforts that must be made is to hold practical lectures at the LPTKs whose content is in accordance with the needs of the business world and the industrial world (DUDI) so that the competence of graduates is in accordance with the needs of the business world and industry.

In the teaching and learning process (PBM) whether the content is in accordance with the content required in the culinary field competency test, an analysis will be carried out of the description and learning outcomes in each subject related to the competency test. Based on the preliminary analysis of the readiness of LSP P1 "Tata Catering" carried out by the PKK Department of Semarang State University, data was obtained that the Catering expertise program had strengthened competencies according to the SKKNI through course practice content. Regarding whether students understand the existence of LSP P1 "Tata Catering" and whether students are ready to take the competency test at LSP P1 "Tata Catering", based on conversations with several students, they said: "Don't really know about the existence of LSP P1" Tata Catering ". and they also said they did not know how the mechanism to follow the competency test". This raises a question, as to whether Catering students are actually prepared to take the competency test in the tourism / culinary field at LSP P1 "Tata Catering" in the Department of Family Welfare Education (PKK), Faculty of Engineering, Unnes.

Based on the findings in the field, it is understood that there are still some deficiencies found related to the readiness of LSP P1 "Food Management" in the PKK department. To better understand this problem, the researcher will express it with "the analysis of the readiness of LSP P1" Tata Catering ", support for the teaching and learning process and the readiness of students for the implementation of competency tests on Unnes and Unesa students".

Based on the research focus, this research can formulate the following problems:

a) How is the Readiness of LSP P1 "Tata Catering 'at UNNES and UNESA?

b) How to Support the Teaching and Learning Process for the implementation of the Competency Test at UNNES and UNESA?

c) How is Student Readiness for the Implementation of Competency Tests at UNNES and UNESA?

\section{Methodology}

This type of research is descriptive research. Descriptive research is a research method that seeks to describe and interpret objects according to what they are. What is meant by descriptive research in this research is research that focuses on actual problems as they were at the time of the research. With descriptive research, researchers try to describe events and incidents that are the center of attention without giving special treatment to these events. The 
subjects of this research are UNNES and Unesa Culinary Education students in semester 5 or 7 who will take the competency test, in this case the research subjects from UNNES are students of class 2017 and research subjects from UNESA are students' class 2017 and class 2018. The object of this research is the existing certification scheme in LSP P-1, the existing learning content (curriculum) in the PKK UNNES and UNESA departments.

The sampling technique in this study was total sampling. Total sampling. The reason for taking total sampling is because according to Sugiyono (2011) the total population is less than 100 , the entire population is used as the research sample for all. To obtain data in this study using document data in the form of certification schemes and certification instruments, process mechanisms and quality of competency test results in LSP P-1, learning content (curriculum) in the PKK UNNES and Unesa departments. For data on the readiness of Catering students for competency tests using tests. The research instrument is a test in the form of google form, where the indicators of this test consist of 23 indicators and 50 questions. Before use, the instrument was tried out with the object having the same characteristics as the object of research. The try out was carried out on 33 students of UNNES class 2018. The data on the difficulty level of the try out results, obtained 19 items with moderate difficulty level, 9 difficult questions and 22 easy questions.

To determine the readiness of LSP P1 "Tata Catering" at UNNES and UNESA as well as support for the teaching and learning process in the implementation of competency tests at UNNES and UNESA were analyzed by comparing the conditions in UNNES and UNESA. Meanwhile, to determine the readiness of student knowledge for the implementation of competency tests at UNNES and UNESA, using descriptive statistics.

In addition, the students' knowledge readiness scores to take the competency test were compared with the assessment criteria at UNNES. According to the 2020 UNNES assessment guidelines in article 4 regarding the assessment criteria, student learning outcomes expressed in letters are as follows:

a) $\mathrm{A}$ if the students' average seed reaches more than 85 to 100

b) $\mathrm{AB}$ if the student average seed reaches more than 80 to 85

c) $\mathrm{B}$ if the students' average seeds reach more than 70 to 80

d) $\mathrm{BC}$ if the students' average seed reaches more than 65 to 70

e) $\mathrm{C}$ if the student average seed reaches more than 60 to 65

f) CD if the students' average seed reaches more than 55 to 60

g) $\mathrm{D}$ if the students' average seed reaches more than 50 to 55

h) E if the students' average seed reaches 50 or less.

At $\mathrm{p}$ origin 5 in the assessment guidelines, saying about the meaning and weight of value has the following meanings:

Table 1. Value and Meaning of Value

\begin{tabular}{ll}
\hline \multicolumn{1}{c}{ Score } & \multicolumn{1}{c}{ Meaning of Value } \\
\hline A & Very well \\
AB & Better than good \\
B & Good \\
BC & More than enough \\
C & Enough \\
CD & Less than enough \\
D & Less \\
E & Failed do not pass \\
\hline
\end{tabular}




\section{Result and Discussion}

The results of this study will describe the problems: Readiness of LSP P1 "Food Order" at UNNES and UNESA, support for the teaching and learning process at UNNES and UNESA for the implementation of the competency test, as well as the readiness of students to take competency tests at UNNES and UNESA.

\section{Readiness of LSP P1 'Food Order' at UNNES and UNESA}

Based on the readiness of LSP P1 'Tata Catering "UNNES and UNESA, comparisons are obtained as follows:

Table 2. Comparison of Readiness of LSP P1 UNNES and UNESA

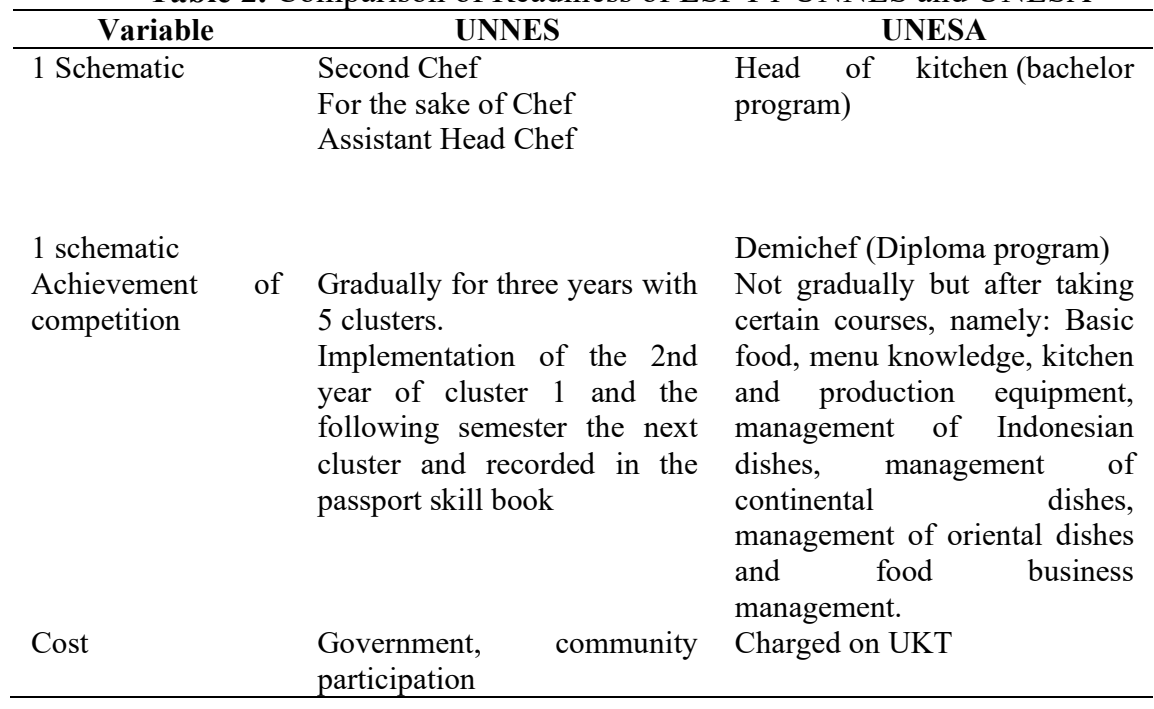

\section{Teaching and Learning Support in UNNES and UNESA Implementation of Test Competence}

At Unnes and Unesa, academic support for the competency test has been well prepared because of the existence of supporting courses that provide the provisions for mastery of the knowledge required for competency tests in the culinary field. Supporting courses at UNNES are: Basic Catering, Continental Food Processing, Food Business Management, Hygiene Sanitation and Work Safety, Management Basics, Administration and English.

Meanwhile, the supporting courses at UNESA are : Basic Culinary, Menu Knowledge, Kitchen and Production Equipment, Indonesian Dishes Management, Continental Dishes Management, Oriental Dishes Management and Catering Business Management .

\section{Readiness Knowledge Students Natural Implementing Competency Test in UNNES and UNESA}

Data readiness UNNES student knowledge before the implementation of the competency test is as Be $r$ participate:

Table 3. Analysis of Knowledge Readiness of Unnes Students 


\begin{tabular}{lcc}
\hline \multicolumn{2}{c}{ Statistics } \\
\hline Value_Unnes & \\
\hline $\mathrm{N}$ & Valid & 48 \\
& Missing & 0 \\
Mean & 60.46 \\
Median & 62.00 \\
Mode & 62 \\
Std. Deviation & 8,034 \\
Minimum & 36 \\
Maximum & 74 \\
\hline
\end{tabular}

Based on the above results known average readiness of the student's knowledge UNNES to follow test competence value of 60.46 . The lowest score of knowledge readiness was 36 and the highest score of knowledge readiness was 74, while the highest score was 62 .

Table 4. Achievement of Unnes Student Knowledge Readiness Value

\begin{tabular}{llcccc}
\hline \multicolumn{5}{c}{ Value_Unnes } \\
\hline Valid & 36 & Frequency & Percent & Valid Percent & Cumulative Percent \\
& 46 & 1 & 2.1 & 2.1 & 2.1 \\
& 1 & 2.1 & 2.1 & 4.2 \\
& 48 & 2 & 4.2 & 4.2 & 8.3 \\
& 50 & 2 & 4.2 & 4.2 & 12.5 \\
& 52 & 5 & 10.4 & 10.4 & 22.9 \\
& 56 & 5 & 10.4 & 10.4 & 33.3 \\
& 58 & 1 & 2.1 & 2.1 & 35.4 \\
60 & 4 & 8.3 & 8.3 & 43.8 \\
& 62 & 7 & 14.6 & 14.6 & 58.3 \\
& 64 & 6 & 12.5 & 12.5 & 70.8 \\
66 & 3 & 6.3 & 6.3 & 87.5 \\
68 & 5 & 10.4 & 10.4 & 91.7 \\
70 & 2 & 4.2 & 4.2 & 97.9 \\
72 & 3 & 6.3 & 6.3 & 100.0 \\
74 & 1 & 2.1 & 2.1 & \\
\hline
\end{tabular}

Based on the readiness scores of UNNES students' knowledge, the following data were obtained: A score: none; AB value: none; Value B: 4 people $(8.33 \%)$; BC Value: 10 people (20.83\%); Value C: 13 people (27.08\%); CD score: 10 people $(20.83 \%)$; D score: 7 people (14.58\%) and E score: 4 people (8.33\%). Data readiness of UNESA students' knowledge prior to the implementation of the competency test are as follows:

Table 5. Analysis of Knowledge Readiness of Unesa Students 


\begin{tabular}{lccc}
\hline \multicolumn{3}{c}{ Statistics } \\
\hline N & Value_D3_Unesa & Value_S1_Unesa \\
& Missing & 20 & 41 \\
Mean & 21 & 0 \\
Median & 59.80 & 58.00 \\
Mode & 60.00 & 60.00 \\
Std. Deviation & 60 & 56 \\
Minimum & 6,771 & 10,705 \\
Maximum & 46 & 28 \\
\hline
\end{tabular}

Based on the results above the average readiness knowledge UNESA undergraduate students to follow competency of value 58. The lowest value of preparedness knowledge is 28 and the highest of knowledge readiness is 76 , while the value of the most appear is the value 56. Based on the above results average readiness knowledge UNESA Diploma program students to follow competence of the value 59.80. The lowest score of knowledge readiness was 46 and the highest score of knowledge readiness was 72, while the highest score was 60 .

Table 6. Achievement of D3 Unesa Student Knowledge Readiness Value

\begin{tabular}{llrrrr}
\hline \multicolumn{5}{c}{ Value_D3_Unesa } \\
\hline Valid & \multicolumn{6}{c}{ Frequency } & Percent & Valid Percent & Cumulative Percent \\
& 46 & 1 & 2.4 & 5.0 & 5.0 \\
& 48 & 1 & 2.4 & 5.0 & 10.0 \\
& 52 & 1 & 2.4 & 5.0 & 15.0 \\
& 54 & 1 & 2.4 & 5.0 & 20.0 \\
& 56 & 2 & 4.9 & 10.0 & 30.0 \\
& 58 & 2 & 4.9 & 10.0 & 40.0 \\
& 60 & 5 & 12.2 & 25.0 & 65.0 \\
& 64 & 3 & 7.3 & 15.0 & 80.0 \\
& 66 & 1 & 2.4 & 5.0 & 85.0 \\
& 68 & 1 & 2.4 & 5.0 & 90.0 \\
& 70 & 1 & 2.4 & 5.0 & 95.0 \\
& 72 & 1 & 2.4 & 5.0 & 100.0 \\
Tissing & System & 21 & 51.2 & 100.0 & \\
\hline & & 41 & 100.0 & & \\
\hline
\end{tabular}

Table 7. Achievement of Knowledge Readiness Value of Undergraduate Students of Unesa

\begin{tabular}{lccccc}
\hline \multicolumn{5}{c}{ Value_S1_Unesa } \\
\hline Valid & 28 & 1 & 2.4 & 2.4 & 2.4 \\
& 36 & 3 & 7.3 & 7.3 & 9.8 \\
& 46 & 2 & 4.9 & 4.9 & 14.6
\end{tabular}




\begin{tabular}{l|cccc}
48 & 2 & 4.9 & 4.9 & 19.5 \\
50 & 1 & 2.4 & 2.4 & 22.0 \\
54 & 1 & 2.4 & 2.4 & 24.4 \\
56 & 7 & 17.1 & 17.1 & 41.5 \\
58 & 3 & 7.3 & 7.3 & 48.8 \\
60 & 2 & 4.9 & 4.9 & 53.7 \\
62 & 4 & 9.8 & 9.8 & 63.4 \\
64 & 2 & 4.9 & 4.9 & 68.3 \\
66 & 6 & 14.6 & 14.6 & 82.9 \\
68 & 3 & 7.3 & 7.3 & 90.2 \\
70 & 2 & 4.9 & 4.9 & 95.1 \\
72 & 1 & 2.4 & 2.4 & 97.6 \\
76 & 1 & 2.4 & 2.4 & 100.0 \\
Total & 41 & 100.0 & 100.0 & \\
\hline
\end{tabular}

Based on the value of the knowledge readiness of UNESA students at the Diploma level, it is described as follows: Value A: none; AB value: none; Grade B: 1 person (5\%); BC Value: 3 people (15\%); Grade C: 3 people (15\%); CD score: 9 people (45\%); D Score: 2 people $(10 \%)$ and E Score: 2 people (10\%). Meanwhile, the value of knowledge readiness of UNESA undergraduate students can be described as follows: A score: none; AB value: none; Grade B: 2 people (4.88\%); BC Value: 11 people $(26.83 \%)$; Value C: 6 people $(14.63 \%)$; CD score: 12 people (29.27\%); D score: 2 people (4.88\%) and E score: 8 people $(19.51 \%)$.

\section{Conclusion}

The conclusions obtained from this research are the readiness of LSP P1 "Catering" at UNNES for the competency test scheme has not been well-defined because one scheme consists of three occupations, namely: Second Chef, Demi Chef, and Assistant Head Chef. Meanwhile, the LSP P1 "Tata Catering" at UNESA has one scheme, there is one occupation, namely for the undergraduate level scheme, the head of the kitchen and the diploma level scheme for the chef. In Unnes and Unesa, academic support for the competency test has been well prepared because of the existence of supporting courses that provide the provisions for mastery of the knowledge required for competency tests in the culinary field. The results of the analysis of the readiness of students' knowledge for the competency test at Unnes: A: none, AB: none, B: 4 (8.33\%), BC: 10 (20.83\%), C value: 13 people (27.08\%), CD value: 10 people $(20.83 \%)$, D value: 7 people $(14.58 \%)$, and E value: 4 people $(8.33 \%)$.

\section{References}

[1] Ali Imron. 2008. Kebijaksanaan Pendidikan di Indonesia, Proses, Produk dan Masa Depannya. Jakarta: Bumi Aksara.

[2] Borg, W.R. \& Gall, M.D. Gall. (1983). Educational Research: An Introduction, Fifth Edition. New York: Longman.

[3] David Nachmias \& Chava Nachmias, Research Methods in the Social Sciences, Third Edition, New York: St. Martin's Press, 1987, page. 10-15.

[4] Emzir. 2009. Metodologi Penelitian Kuantitatif \& Kualitatif, (Jakarta: PT Rajagrafindo 
Persada,), hal 28

[5] Jurusan Teknologi Jasa dan Produksi. 2010. Silabus. Semarang: FT UNNES.

[6] Menteri Pendidikan Nasional. 2000. Keputusan Menteri Pendidikan Nasional Nomor: 232/U/2000 tentang Pedoman Penyusunan Kurikulum Perguruan Tinggi dan Penilaian Hasil Belajar Siswa.

[7] Mitchell, T. R. Research in Organizational Behavior. Greenwich, CT: JAI Press, 1997, hal. 6062.

[8] Ni Putu Suzy Puspita Dewi, Gede Rasben Dantes, dan Gede Indrawan. 2018. Evaluasi Usability pada Aspek Satisfaction Menggunakan Teknik Kuesioner pada Sistem LMS Program Keahlian Ganda. Program Pascasarjana Universitas Pendidikan Ganesha, Jurnal Pendidikan Teknologi dan Kejuruan Vol. 15, No. 1, Januari 2018, Hal: 60 P-ISSN: 0216-3241 ; E-ISSN: 2541-0652.

[9] Paul.D. Leedy and Jeanne.E. Ormrod. Practical Research: Planning and Design Research Edisi 8 [2005]. Ohio : Pearson Merrill Prentice Hall. Page 145-187.

[10] PPPPTI BMTI. 2018. Pembekalan MUK dan Uji Kompetensi bagi Guru SMK Negeri 2 Bogor Periode: 09 S.D. 11 Januari 2018 Di PPPPTK BMTI, Kota Cimahi, Provinsi Jawa Barat.

[11] Robbins, Stephen P.; Judge, Timothy A. (2008). Perilaku Organisasi Buku 1, Jakarta: Salemba Empat. Hal.222-232.

[12] Santoso, Tjiptono. 2001. Riset Pemasaran Jasa. Andi Offset: Yogyakarta.

[13] Wijaya, M. Adib, H.Yoto dan Syarif Suhartadi. 2018. Studi Pengelolaan Program Guru Keahlian Ganda pada Kompetensi Keahlian Teknik Kendaraan Ringan Otomotif di SMKN 1 Singosari. Malang: Jurusan Teknik Mesin, Fakultas Teknik, Universitas Negeri Malang.

[14] https://www.wartaekonomi.co.id/read183079/kemenpar-industri-pariwisata-wajib-milikisertifikasi-kompetensi.html. Download 5 September 2019 23:45.

[15] https://ekonomi.bisnis.com/read/20190815/12/1137143/target-kunjungan-wisman-2019-jauhpanggang-dari-api. Download 22 Oktober 2019 05:50.

[16] https://www.dkampus.com/2016/03/memahami-metode-pendekatan-penelitian-kuantitatif/

[17] https://id.wikipedia.org/wiki/Penelitian eksplanatori

[18] http://direktoritraining.com/daftar-lembaga-sertifikasi-profesi-lsp-di-indonesia/ 